\title{
VAlUe-AdDed: Consulting MiKhAIL BAKHTIN ABOUT WESTERN CHRISTIAN EUCHARIST
}

MAIS-VALIA : CONSULTANDO MIKHAÏL BAKHTIN

SOBRE A EUCARISTIA CRISTÃ NO OCIDENTE

BARBARA GREen $^{(*)}$

\begin{abstract}
In this study, I aim to demonstrate how Bakhtin's basic dialogic framework-specifically his understanding of how an author constructs a hero from which can be extrapolated how any one of us constructs an other - can add insight to the ways in which we might understand the Eucharist so that its ritual character is more relevant, more aligned with nonviolence, and more available to draw on in "prosaic" life than we might think it to be. I sketch briefly three relevant discourses that offer access to the Eucharist: First, some basic points about the Eucharist as cultic, then an adumbration of the violence question, and finally the relevant contribution of Bakhtin. I will conclude with some implications and suggestions for the development of insights. KEYWORDS: Eucharist. Violence. Nonviolence. Bakhtin.
\end{abstract}

\section{RESUMO}

Com esse estudo, assumo como objectivo demonstrar como o quadro dialógico fundamental de Bakhtin - especificamente o seu entendimento de como um autor constrói um herói, a partir do qual se pode determinar também a forma como se constrói o outro - pode abrir para uma forma de compreensão da Eucaristia em que o seu caráter ritual seja mais relevante, mais alinhado com a não-violência e de maior impacto na vida "prosaica". Esboço três breves discursos relevantes que conduzem à Eucaristia: em primeiro lugar, alguns pontos básicos sobre a Eucaristia como culto, em seguida, um esboço da questão da violência, e, finalmente, a principal contribuição de Bakhtin. Concluo com algumas implicações e sugestões para o desenvolvimento da proposta.

PALAVRAS-CHAVE: Eucaristia. Violência. Não-violência. Bakhtin.

\section{INTRODUCTION}

Can the distinctive thought of Mikhail Bakhtin-philosopher, anthropologist, and literary theorist-add anything valuable to our current understanding of the Western Christian Eucharist? Given that he was Russian Orthodox, lived his life co-terminous with the Soviet Union, never wrote on the Eucharist as it is familiar to Western Christians, and of course did not imagine our twenty-first century issues, it seems perhaps an unlikely wager.

\footnotetext{
${ }^{(*)}$ PhD, Graduate Theological Union \& University of California, Berkeley; MA, Graduate Theological Union; BA, Dominican College of San Rafael.
} 
Among the many contexts in which the contemporary Christian Eucharist can be placed, I would offer as urgent a set that is more linguistic and social than theological, or discussed in literary/anthropological rather than strictly theological terms: First is the gradual modern or postmodern disinterest in and disregard for religion, challenging those for whom it remains important to understand it deeply and be able to discuss it helpfully (TAYLOR, 2007). Second, the challenges the Eucharist faces, with its genetics of blood sacrifice bearing a consequent Christian complicity in violence, a potential scandal in a world wracked by increasingly sophisticated and deadly force (DE VILLIERS; VAN Henten, 2012). And third, a problem distinctive in Catholic Christianity, the looming absence of the transformative Eucharist from the active lives of many people due to a shortage of ordained males to preside at Eucharistic liturgy (STEINFELS, 2003). Insofar as eucharistic participation becomes less regular and able to be counted upon, its effects can seem to slip away. Again, can Bakhtin offer anything useful to these problems?

I suggest and aim to demonstrate how Bakhtin's basic dialogic framework-specifically his understanding of how an author constructs a hero from which can be extrapolated how any one of us constructs an other-can add insight to the ways in which we might understand the Eucharist so that its ritual character is more relevant, more aligned with nonviolence, and more available to draw on in "prosaic" life than we might think it to be.

I offer and sketch briefly three relevant discourses that offer access to the Eucharist, culminating each section by naming the most apt way in which the significance of Eucharist can be addressed, finally guiding them into collaboration with each other: First, some basic points about the Eucharist as cultic, then an adumbration of the violence question as understood by at least some, and finally the relevant contribution of Bakhtin. I will conclude with some implications and suggestions for the development of insights.

My qualifications for addressing this issue are quixotic, to put it generously. My main and lifetime interest is biblical studies and spirituality, specifically Old Testament texts. While searching for a coherent methodology as the melée of literary and reader-centered methods was challenging and indeed overrunning the long-running hegemony of historical studies within my biblical studies field (in the mid-1980s or so), I looked for a thinker who could "do it all": offer an interpretive framework that was respectful though a bit agnostic about the likelihood of historical reconstruction, be adept and skillful 
in bringing out the literary aspect of narrative, and be pushed to take advantage of culture- and reader-alert methods of interpretation ${ }^{1}$. Bakhtin seemed and has proven to be a solid bet (GREEN, 2000 and 2003). I know less than is ideal about Eucharistic theology as it has developed over the past twenty centuries and so will focus on the biblical narratives themselves, remaining at a rather general level. As a practicing Roman Catholic with a deep love for the Eucharist and grateful if intermittent participation in vital Eucharistic communitiesintermittent because there are relatively few of them-I have an experiential urgency about the topic. Finally, a long interest in the dynamics of nonviolence, aided by long and close study of giants like Mohandas Gandhi and Martin King and behaviorists like Marshall Rosenberg, coupled with the opportunity to work with some of the thought of René Girard on mimetic violence, has encouraged me to attempt this analysis.

\section{THE EUCHARIST AS A PHENOMENON}

The Eucharist as presented in the New Testament can be usefully envisioned as having four "grandparents" with persuasive and enduring DNA (other forebears could be named as well, of course, but these seem apt): As it emerges in the synoptic Gospels (Mark 13, Matthew 26, Luke 23), the language of the words over the cup stress its retaining its character as a blood sacrifice ritual; it has also become a shared meal of remembrance (Passover), maintaining a link to a blood ritual and to the liberation of some and the death of others (Exodus 12, 15); it participates, as all sacrifices do, in what we can call a gift economy, the impulse to exchange goods with those with whom we relate (MAUSS, 1990; and WEINER, 1992); and it is the narrative of the final evening of a man who is about to die, the story of his offering his friends access to a process of transformation, related to and dependent on what he himself is about to undergo. In this present discussion, the inter-penetration and collaboration of these elements will remain powerfully operative as the Eucharist undergoes centuries of theologizing (a process not engaged here) (KILMARTIN, 1998; SCHILLEBEECKX, 1968).

\footnotetext{
${ }^{1}$ In fact, as I review my own practice of introducing Bakhtin when I am occasionally asked to present "him" to a class, usually in a three-hour period, it strikes me that the most important goal to accomplish is to whet the thirst of the reader rather than try to summarize his ideas in any global sense. I became interested in Bakhtin because I liked the use made of his work by Robert Polzin, who was then writing on facets of the Deuteronomistic History (Polzin, 1980, 1989, 1993). Polzin did not explain very specifically how or why Bakhtin worked effectively so much as demonstrate that he did, enough to woo me and numerous others to investigate for ourselves.
} 
What else can we say about the contribution of these "bloodlines"? First, we note that a phenomenon of human worship seems to be the impulse to shed blood for some complex of reasons, little known to us now ${ }^{2}$. The Last Supper (partial context for the Eucharist) draws on the language of the Sinai/Horeb covenant (Exodus 19, 24) to suggest that the blood of slain animals is somehow and for some reason attached to the people participating (splashed on them at the mountain, given them to drink at the meal [granted the vast difference, especially to Jewish ears, between being sprinkled with blood and being offered it to drink]). The Sinai/Horeb covenant blood, also offered to the deity at whose command the ceremony is being enacted, bonds participants. To participate in ritual allows us to identify with revered others (including with the unseen divine) in sacred acts, to preserve our social links with other humans, to accomplish purposes of solidarity with the past (USHER, 2010; BELL, 1996). However, the Last Supper as narrated in the gospels more strongly resembles a Passover meal than it does the Sinai/Horeb covenant ceremony, while retaining its links with both covenant blood and the Passover lamb-slain both to identify the lintels of those to be preserved (and implicitly, those not so protected) and to enable those marked to partake of the Passover meal itself, whose main staple was a lamb or a goat and unleavened bread. So in both cases the ritual involves the shedding of the blood of one creature for the good of others, with an implicit negative undertow of one benefitting at the expense of another. Part of the ritual involves narrative: Participants tell a story while accomplishing the ritual and repeat it on subsequent occasions. Fluid and fertile narrativizing serves to assist participants in their understanding of the deed, to make it comprehensible for others who will come later, notably those who may understand less well than those who tell the story. It is possible and in fact necessary to widen and deepen meaning, to add stories that continue to fill the ritual deed fuller than it started, even as some old understanding may fade out. Such enriching is salutary while also marking for us places for helpfully questioning tradition, the more adequately to understand it.

The synoptic Last Supper story-including not simply the meal but the events prior and subsequent to it-brings with it an ancient Hebrew and Jewish heritage that is widened as it gathers at the last Passover Jesus celebrates with his disciples and friends, adds all of its "original” or early significance to a fresh

\footnotetext{
${ }^{2}$ Classicist Walter Burkert among many other claims that blood and violence lurk fascinatingly at the very heart of religion and underlie the experience of the sacred. See BURKERT, 1986. Another who writes on the topic is ARMSTRONG, 2009, p. ix-xviii.
} 
act which, at a certain level, takes over and even hijacks the first meaning with what happens at the end of the meal. Better: The Jewish ritual and narrative significance of the meal is enhanced for Christians as the story of Jesus' arrest, trial and death are told, with particular emphasis on the manner in which he experienced those events and as others (including the evangelists and putatively the figures whose experience they relate) came to interpret them. And the point of Jesus' friends continuing to participate in the Eucharist and to understand its significance as deeply as possible is not simply nostalgic but aimed at transformation: What Jesus was able to do and how he was able to do it is part of the gift and challenge he handed on that evening to his friends. To share in the meal is to have the opportunity for transformation. The very action of ingesting food, digesting it, converting it to energy for mission makes that clear at a most basic level. The question to probe is how that is to happen as participants, through time, enact a symbolic meal and share, consume bread-asbody and wine-as-blood and deal with opponents, as Jesus himself did and his ancestors ahead of him (see, for example, Luke 23-24 for perhaps the best working out of the transaction under discussion here). As participants theorize about the deep meaning of the experienced and recited ritual, a theology develops over time while maintaining its links with the base tradition.

Questions to probe: How does the inherited sacrificial character of the biblical narrative, specifically its links to blood sacrifice, prompt interpretation? How is the narrative of the Last Supper and related events recited so that its primordial power remains present? How can Christians appreciate the safety/salvation conferred by the Lamb's blood without misappropriating the binary potential: good saved, bad lost? How can the narrative be inhabited so that its Hebrew/Jewish roots are respected while its transformed Christic character is maintained?

\section{THE VIOLENCE QUESTION}

The close links with blood sacrifice and the suggestion that the blood of the slain Passover lamb advantages the Hebrews to the cost of the Egyptians is an uncomfortable datum. And yet it seems undeniable that ancients, at least as far back as can be known, participated in such an understanding. To seek to silence these roots is, arguably a sort of false or naïve hope for utter innocence, a wish to stand unchallenged on a rock or righteousness regretting that sacrificial blood is involved in the Eucharist. But it is, and so the question is how to understand and construe that reality. For that challenge, the work of Girard and 
especially the next generation of his colleagues (a group I will call neoGirardians) is most helpful to characterize social and specifically religious violence in ways that offer fresh approach to it3.

Girard's basic insight, developed and nuanced over time, is that mimetic or imitative violence is widely characteristic of Western culture and hence powerfully typical of how western humans act and interpret, including how we interpret God's actions in Scripture and elsewhere. This particular projection of violence onto the deity is called "sacral violence" to suggest divine sanction. Components of violence as owned generally by neo-Girardians include the following: First, desire is mimetic, so cultural and not simply biological or natural. We desire what others desire. Hence, second, we are intensively intertwined in each others' lives, not simply autonomous, since we are caught in webs of desiring what others desire. Third: Such desire is expressed acquisitively and specifically (though likely rooted in metaphysical desire). Some mimetic desire is inevitable and productive, since it is how societies and groups bond within. A fourth point: Along a spectrum, desire is recognized as more internal (with "lower walls" between us) or external (with higher barriers and less danger of our actually tangling). In internal rivalry, closely associated opponents come to resemble each other (without recognizing it), allowing a near rival (called in this discourse a "model,") to become a rival. Fifth: A typical or a standard mimetic or rivalrous situation develops as a by-product/cause of social disorder that seems to demand resolution. Disintegration is a constant threat to culture, happening often and for various reasons. It is feared, reacted to, met with violence. Rivalry itself is a major motor of such disorder. A social group (sixth), typically unaware of what it is doing, seeks to remedy the disorder by identifying a culprit (called the scapegoat) who is 'not us,' charging it with being the cause of the problem. To sacrifice the scapegoat/ostensible cause of the disorderly situation and then to claim that its sacrifice also brought about new order (a pair of moves called a double transference), allows the group to see, explain, and justify the violence as necessary. Seventh: Cultures/groups that do/have done this tend to hide it from themselves, hedging the act with ritual to make the action approved (e.g., sacrifice) and establish taboos that protect them from too much rivalrous desire (e.g., quarantines of killing). Such rituals and boundaries are often part of "religion,"i.e., made part of divine order (of sacral

3 For a good introduction to Girard, see WILLIAMS, 1996; ALISON, 1993; KIRWAN, 2005; ASTELL GOODHEART, 2011. In a sentence, Astell and Goodhart sum up Girard: “... all culture is founded upon murder, upon the collective lynching of a surrogate victim or scapegoat whose removal restores peace and tranquility to a previously disrupted community" (ASTELL - GOODHEART, 2011, p. 3). 
or religiously sanctioned violence). But such secondary violence-especially insofar as it is unacknowledged-cannot really cure the problem of root or primary violence. Some 'pale' or bloodless indicators of the presence of mimetic rivalry include the tendency to compare ourselves favorably to others, to compete, to accuse and blame them and justify ourselves; to be envious and jealous of what others have and might want. This dense but general summary can be filled out and nuanced in many ways but will suffice for present purposes.

It is not difficult to sense that the pattern fits certain biblical narratives closely. Being part of western culture, the Bible unavoidably participates in this same patterns that characterize the larger matrix. There are a number of texts where the lens of mimetic desire seems to work-the Cain and Abel narrative (Genesis 4) comes to mind, the Aqedah/Binding or Sacrifice of Isaac (Genesis 22), the narratives of Joseph and his brothers (Genesis 37-50)-though in each case careful exegetical and interpretive work needs to be done to detect and demonstrate specifically how the pattern is present. The Hebrew system of expiatory sacrifice seems suggested, not least the mysterious ritual of Leviticus 16 where a scapegoat is loaded with the sins of the community and sent off. Though it is minimally safe to say that sometimes the pattern seems approved and even claimed for God's ways of dealing-the Bible thus can seem to assume and endorse sacral violence-in certain instances, the mimetic desire pattern may be seen, at least by those reading carefully and critically, to be subverted. Notable among such passages are the last Isaian servant poem (Isaiah 52:1353:12) and the life, passion, death, and resurrection of Jesus, cumulatively and particularly in the Gospel of John (chs. 13-20). The simple valorization of Christianity over against other culture patterns not only does not hold up but is itself part of the pattern of violence. That is, to claim vauntingly and uncritically that "Christian love" solves a "Jewish violence" problem is not only too optimistic a claim but contributes to the problem under discussion, practically speaking, since historic Christianity has participated heavily in mimetic and sacral violence especially against Jews. To claim that the Isaian servant survives or transcends the violence 'he' suffers can be done, constructively, calling attention to certain features of the passage; care must be taken in identifying the dynamic, and the reader will need to acknowledge substantial ambiguity in the passage, productive in some cases and frustrating in others.

The NT material is fuller (comprising really all four gospels and many other places where the life and death of Jesus are characterized), works well to 
fill out the neo-Girardian paradigm, but care needs to be taken to interpret that material as well. Narrative factors seem able to argue for the pattern as present and utilized by God (sacral violence, e.g., classic atonement theory: HEIM, 2006) or as subverted. But the "text" does not decide on its own. Crucial and grounding is the stance of the interpreter on the matter of theology and anthropology. Certain NT scholars and theologians (e.g., Alison, Heim) bring the neo-Girardian lens to their work and make the case for the life/passion/death/resurrection of Jesus as subverting the pattern and opposing any sense of sacral violence. These, like the theologies they aim to correct, are powerfully constructive, since there is not really any way to actually diagnose God's specific moves. Alison and Heim claim that the action of Jesus/God/Holy Spirit disarmed and exposed the pattern of mimetic violence, making it able to be seen through (temporarily? by some?) and thus throughly discredited. Alison's 'intelligence of the victim' and Heim's double-optic are their ways of showing this, and a byproduct of their analysis is to call into question the classic theory of atonement and its theology and anthropology.

The mimetic violence analysis poses some crucial questions, more than can be engaged here. How, at base, do we understand God's desires in terms of the death of Jesus: Possibilities range from positing an angry and affronted deity demanding satisfaction blood of a victim... to a deity grieving at the struggles of creatures and assisting where possible. How do we interpret the narrative of opponents of Jesus putting him to death and his friends failing to assist him: Do we vilify the Jewish authorities who look for a scapegoat to resolve their current struggles with the Romans, characterize the disciples as spineless-except for the valorization of a few? As we retell and inhabit the narrative, do we cast ourselves as heroic and the others as flawed, taking the opportunity to exclude from participation the unworthy, whoever and however designated they may be4? In other words, do we re-inscribe mimetic violence or seek to break the pattern?

\section{BAKHTIN'S RELEVANCE}

A quick overview of the man and his lifework is called for, since we will be dipping as surgically as possible into one piece of it and need to do it both responsibly and productively. Mikhail Bakhtin (1895-1975) was a Russian

4 Astell and Goodhart (2011, p. 9-10) move in a somewhat different and more technical direction with their inquiry, suggesting that the urgent issues involve the nature and valence of substitution, ranging from the logic of the exchange of one victim for another, through the possibility of the exchange of one mechanism for another, through to the demonstration that the whole mechanism of substitution is flawed, failed. 
Orthodox "thinker," more precisely, a philosopher, an anthropologist, an historian of Hellenistic literature, a literary theorist, a specialist in Rabelais, a scholar of the novels of Dostoevsky5.

Though he worked in relative isolation from other modern language philosophers such as Martin Heidegger, Hans Georg Gadamer, and Paul Ricoeur, his ideas are roughly compatible with theirs; readers familiar with twentieth-century hermeneutics will find much that they recognize in Bakhtin, granted his terminology is idiosyncratic and certain emphases distinctive. Restricted to classic material available in the USSR (much of which he had by memory), his primary contemporary conversation partners (including opponents) were other Russian theorists rather than Europeans, and the subtext under negotiation was Soviet ideology, which Bakhtin consistently resisted. Since Bakhtin's ideas were accumulated in notebooks over the course of his life rather than prepared with publication in mind, they are not easy to consult in an orderly or convenient way. Bakhtin specialists argue over the extent to which his ideas changed over the course of his lifetime. For those of us who know considerably less about the thought universe of western philosophy, the point seems moot; the consistency/shift issue is primarily diagnostic of our sense that we understand Bakhtin well enough to use his ideas responsibly for work with the Bible. Bakhtin himself apparently did not envision and certainly did not implement his own ideas about literature in terms of the biblical text, supposing that the Bible was not amenable to strategies used on non-inspired texts. But whether he would approve or not, his theories of language and literature, worked out primarily with Russian novels, have been recognized as fruitful by scholars in many other fields, Old and New Testaments included. Certain Russian specialists on Bakhtin tend to be leery of such efforts, as are some scholars whose primary interest is the history of ideas. But if relevance is to be sought in terms of productivity, the Bakhtin and the Bible industry is booming, whatever the future may hold.

Before moving to the part of his thought most directly useful to the present project, let me offer one additional and crucial insight drawn primarily from the work of Ruth Coates, who has sought to root Bakhtin's thought in Christian (actually biblical) theology and its wider world view (MIHAILOVIC, 1997; and CoATEs, 1998). Coates argues that and demonstrates how his

5 For biographical information on Bakhtin, consult CLARK; HOLQUIST, 1984, which unfolds the man's life as it discusses his work. An alternate biographical scenario is offered by HIRSCHKOP, 1999, ch. 3. 
anthropology/theology and literary-critical insights and strategies take shape from the continuous and simultaneous processes visible in biblical dynamics which include God and creatures, authors and characters, authors and readersthe whole process of using language: God is engaged in authoring: giving shape, sharing self, making an other known, a deed done exotopically (from the outside) but intimately, unfinalizably and provisionally. In this relationship of creator to creatures there comes to visibility a splitting or breach among participants, the awareness of split or chasm among persons, awareness of what separates or lacks between and among consciousnesses; the root of this split is the illusion of self-sufficiency. Required is a kenotic action: One relinquishes in some way a position which might be claimed in order to lean toward others deeply. Such moments of "sympathetic co-understanding" both confer a gift on the other and enhance the experience of the giver. This action invites and often engenders a response: assisted by grace it varies, but is ideally deep and free (not imposed by the giver). There is a recognition that alterity provides the edge, the sense that we are distinctive but linked.

Though the Bible does not talk theoretically about these processes, it articulates them pervasively and is thus receptive to Bakhtin's constellating of them. Though Christians are likely to see the incarnation events of the NT as "the" place for this basic biblical pattern, the OT has its own pervasive traces of God's leaning toward creation in torah (instruction-become-law), in shekinah (abiding presence), in hokmah (wisdom). These are biblical processes, not Christian per se, granted for Christians they are clearest in Jesus. The point: Bakhtin's thought is not foreign to the Bible but born and nurtured there, adumbrating its dynamics and grounding the suitability of allowing Bakhtin to assist us with the dynamic of the Eucharist.

To allow him to do so, we name three aspects of this thought. First, his most basic insight, well-integrated into Western thought in the last hundred years since he and others stressed it, is that all reality and certainly literary language is dialogic. Creator and creatures, authors and readers, narrators and characters, texts and their participants are interactively linked in myriad ways, all of which beg to be investigated appropriately. Old words come to new sites laden with their pasts; genres remember former uses of them. There is no end to what can be related as we make use of the dialogic, not simply at the epistemological level but at the level of careful artistry. Second, and related: The broadly cultural context of a text (including its historical, sociological, economic, religious aspects) is utterly inseparable from the language 
dimensions. Bakhtin sensed no split between life and language, the "historical" and the "literary," such as critical biblical studies has nurtured in modern times. His base assumption that language is thoroughly social and particular makes a useful benchmark for recent efforts in biblical studies seeking to integrate them-or better, to show all dimensions of biblical language richly interrelated. Perhaps the genre "ritual" helps us see how words and actions, saying and effecting go together more naturally than we may sometimes think. A third point is, again, related to the previous pair. Bakhtin, in a strangely contemporary as well as in an ancient way, considered the processes of authoring and reading to be ethically rooted, as Coates helps us see, in the artistry of creation itself. Cued by the title of one of Bakhtin's early works, Art and Answerability, and Clark and Holquist have named Bakhtin's life workincluding but not limited to his literary projects-the Architectonics of Answerability (BAKHTIN, 1990; and Clark; Holquist, 1984, p. 63-94). By answerability he meant, roughly, the need for the interpreter (author, character, or reader) to deal with life's urgent matters and to do so at all levels of life and art from a place of commitment. It is not so unexpected to understand that writers in the USSR needed to take care to stand behind their words-to sign them, as Bakhtin said-but also to weigh constantly what needed to be said and could be said with integrity and also with the hope of survival. The rich facet of his thought distilling here that works most usefully to the question of how to understand the Eucharist in terms of nonviolence is his concept of authoring. Bakthin's sense of how an author draws a hero (his word for what we would call a richly developed character) is related to his sense of how God creates (at one end of a spectrum we can consider) and how any one of us ideally but quite possibly treats another one of us (at the other end). That is, he has a process for talking about how we "other" healthily, nonviolently, we may say. Relevant is the arrest, trial death and resurrection context that grounds the Eucharist: How Jesus and God seem to have conceived the events, how the events were understood by participants and moved into language, how the narrative has been enriched over time as two thousand years of participants have filled it fuller.

For present purposes and with regrettable simplification, we will consider Bakhtin's contribution here in seven steps. First, concentrically: At its most inclusive, authoring is an architectonics of consciousness, a subject's attempt to make sense of the world and to make coherent the role of the self in that world: "Authorship is the primary activity of all selves in a world dominated by the self/other distinction" (ClaRK; HolquIST, 1984, p. 94). So whether-as-we are 
thinking of God interacting with creatures, a self authoring a deed or a work of art, a subject working on a critical (auto)biography, a parent dealing in a healthy way with a maturing child, a literary artist shaping a character-or Jesus himself, sharing a significant ritual meal with his friends and facing his opponents on the eve of his death and seeking to do it ethically, the dynamics can be seen as fundamentally homologous. Second, constant and crucial is a clear distinction between the self and the others, coupled with their simultaneous intensive relatedness; I and the other(s) maintain distinct consciousnesses, for all of the binding factors. The author proceeds from a position of substantial self-knowledge but always retains a blindspot about the self, the back of my own head that I cannot see. Concomitantly, the authoring one sees much about the character being authored but avoids finalizing the other, resists assuming that all is or can be known. Violations are obviously possible here, but done respectfully, balance is maintained.

Third point: Authoring is inevitably, profoundly self-implicating and selfrevealing. For Bakhtin, an author is always doing a self-portrait while drawing an other, is always reaching toward the other dialogically while constructing the self. The other we shape is, to a great extent, an exploration of the self; the response of the other is needed for us to find our own edges. Authoring is thus intensely ethical, with all the potential for creating and experiencing weal or woe. Morson and Emerson remind us that a self-portrait and even a scrutiny of the self in the mirror is never the same as the drawing or viewing of us by another (BAKHTIN, 1990, p. 74) ${ }^{6}$. For Bakhtin, fourth, the process can work along a spectrum running from the imposition of identity by force and extending to a sort of laissez-faire and non-involved relationality, but optimally falling between them, comprising a respectful and generative construction that makes use of both the otherness and the relatedness. That is, when done well, the author avoids both taking over the other so that self-determination is eclipsed and also refuses to abandon responsibility such that the other swamps the author. The challenge for both (all) is to engage intentionally and respectfully, overlapping and intersecting without subsuming or being subsumed. The process thus includes engaging, offering something of value, conferring respectfully such that both author and hero (giver and receiver, self

\footnotetext{
6 For a very comprehensive discussion of Bakhtin and authoring, see MORSON; EMERSON, 1990, chapters $4-5$. It is a valuable supplement to this short summary, which seeks to specify authoring much more pointedly.
} 
and other) are changed but then disengaging and returning to one's place, changed but not absorbed.

A fifth step articulates the process in more technical language: When an author acts, creates in the sense we are discussing here, the process includes something like the following for Bakhtin: She7, starting from her unique and exotopic situation (with whatever attainments and lacks), begins to articulate a literary character, leaning toward and living into that hero, shaping him with all that she knows of herself but also committing to explore what she does not yet know. The author's subjectivity is rendered as an object, thrown outside of herself, as it were. What she authors will be populated by all that she has already become as a human being; so her ethical/moral/spiritual/ religious self is what is cast forward as she authors, with whatever quality it bears at that moment, all contributing to what she wishes to understand additionally ${ }^{8}$. She sees, because of her position or angle outside the hero, some facets of that character of which he is not conscious; concomitantly, there are aspects of her own being that remain opaque to her which will construct the hero as well and will, ideally, become more available to her. Bakhtin says of this moment: "When I contemplate a human being who is situated outside and over against me, our concrete, actually experienced horizons do not coincide. For at each given moment. . . I shall always see and know something that he, from his place outside and over against me, cannot see himself... As we gaze at each other, two different worlds are reflected in the pupils of our eyes9. Such is Bakhtin's aestheticization of a hero, with the project becoming aesthetic to the degree that second consciousness (the hero's embodied discourse) has its own logic and coherence, distinct from the author's. Bakhtin's name for this balance is rendered, somewhat awkwardly in English, "sympathetic co-experiencing" (BAKHTIN, 1990, p. 81).

A sixth point: For Bakhtin, the process is not abstract but embodied, specified as to time and place ${ }^{10}$, cultural particulars, language, with those edges shaping the inner life of the hero along an axis from the more already-known

\footnotetext{
7 Temporarily and for purposes of pronominal efficiency as well as ideology, my author is female, my hero male, and my own relationship with readers represented in the first person.

8 Part of the implication of the author-hero relationship, neither equal nor separate, neither fused nor disengaged, is that the author does not act without bringing his or her own ethical or axiological identity to the deed (PALMIERI, 1998). "It" is constitutive of all authoring.

9 This piece by Bakhtin is part of the work now edited as Art and Answerability (BAKHTIN, 1990), assumed to have been written ca. 1920-23. The quote is on p. 22.

${ }^{10}$ For the spatial discussion, see BAKHTIN, 1990, p. 22-42; for the temporal, see p. 99-132.
} 
and controlled toward what is more free of finalizing management and less controlling ${ }^{11}$. The author builds the character with language, authors him to be a speaking consciousness (PALMIERI, 1998, p. 52). Typically, the author meets the other at a crucial moment, makes such a hero to face a serious crisis or dilemma upon which he ruminates in some relationship with others: how to act, what to do or not to do. What is created, Bakhtin insists, is not a psychology but language around consciousness, orchestrated but not fully controlled by the author; heroes are drawn primarily in terms of their own speech. That language becomes available for interpretation. Again Morson and Emerson sum up: "The author's task, therefore, is to organize a concrete world with three attributes: a spatial world with a living body as its value-generating center, a temporal world with a soul at its center, and a world endowed with meaning as the unity of the two" (MORSON; EMERSON, 1990, p. 78). The challenge is twofold: How to do the hero's soul (remembering that "soul" for Bakhtin is a gift granted by an outside other) so that it is coherent without foreclosing growth, how to build in, without losing authorial control, the possibility for the hero to exceed expectations. The hero requires such authoring: "For Bakhtin, selves are creative in response to images of themselves given by others" (MORSON; EMERSON, 1990, p. 191). A similar case can be made for "live" relationships: "One needs the limitations of one’s own past and of other selves” (MORSON; EMERSON, 1990, p. 230).

Finally, seventh: The gain is what the artist has learned and experienced while authoring another who does not coincide exactly with herself but with whom she is clearly intermeshed in many significant ways. An author comes to be herself more intensively--through gifts bestowed by the other (the hero); she authors a hero who begins his part in authoring her ${ }^{12}$. The key task here is for the author to see herself-if temporarily, repeatedly and perhaps habitually-as through the eyes and ears of another, which will involve seeing something that is new to herself-an appropriate the gift. Such an aesthetic-and ethical-event comprises the process by which the author approaches herself as a living subject through her relation to the fictional hero (PATTERSON, 1991 and 1993). Hence the possibility of transformation. "In order to live as I, the author must become other to [her]self," concludes Patterson (1993, p. 60). And though he is

11 COATES, 1998, chapter 5, and others, judge that Bakhtin never quite satisfactorily resolved the tremendous problems implicit in his theory of polyphonic authoring; nor, perhaps, have philosophers or theologians quite resolved the enigma of God's sovereign authority and human freedom.

${ }_{12}$ As scholars agree, this is the moment in which spirit becomes soul, resulting from an encounter with an other. Dialogism aestheticizes spirit, which means that this particular way of writing gives form to responsibility; giving soul is the task of aesthetics--ethics too, and religion. It is awkward and artificial to talk about the author without talking about the hero's and readers' part of this "dance" as well. 
criticized, justifiably, for presuming that such interaction is typically benign, such a view is indeed part of what Bakhtin posits: "Only sympathetic coexperiencing has the power to conjoin or unite harmoniously the inward and the outward on one and the same plane. From within a co-experienced life itself, there is no access to the aesthetic value of what is outward in the same life (the body). It is only love (as an active approach to another human being) that unites an inner life. . . with the value of the body as experienced from outside and, in so doing, constitutes a unitary and unique human being as an aesthetic phenomenon (BAKHTIN, 1990, p. 82-83).

Bakhtin, then, sharpens issues already-literally-on the table: How do we conceive of the creator's authoring of creatures? Is it tight and controlling, loose and unconcerned-or if something else, how do we see it? If, following Bakhtin, such authoring is gracious and intent without being either too heavy-handed or too permissive, how does it look? Our best hint lies in the manner in which Jesus deals with his "others," whether they are those who arrest, try, sentence and execute him or those who allowed him to wash their feet, who received his gifts of bread and wine re-named as his body and blood, heard his last words and were with him at the moment of his arrest, though absenting themselves shortly thereafter? Bakhtin's sympathetic co-experiential authoring challenges us to see Jesus as aware of all the dynamics, neither resisting and refusing nor caving in easily to his others. He does not fight back and discourages others from doing so, but he does not cease to interact with those who do not wish him well, engaging them as deeply as they allow. He neither takes them over and forces his authority on them, nor does he allow them to so colonize him that he becomes complicit in their acts. Engaging in the moment without hostility, he prays for the forgiveness of those who kill him and-raised from the dead and thus approved by God-reconciles with those he loves without blaming them.

\section{MiXING IT UP}

What, then, can se say about the Eucharist, given the three optics we have just utilized? Having widened our sense of what the Eucharist entails, how are we challenged by the interaction of these characteristic features? Another way to explore implications is to probe the claim that to participate in the Eucharist is to be included in the dynamics just discussed: cultic-narrative action involving the web of allegiances among participants; challenges of mimetic violence with scapegoating propensities; the inevitable intersection among beings with potential for both malign and benign authoring. Is blood unfailingly 
divisive? Do our narratives, rising from the sense of radically limited goods, inevitably valorize ourselves at the expense of the other? Is our innate and inherent tendency to "other" competitively and viciously, seeking our own good and diminishing the other?

These moves are surely not alien to us, but I think the Eucharist sees and shows a different horizon: At the Passover meal celebrating God's gift of liberation, and on the eve of his own journey from life to death (to Life), Jesus offered food for the journey, his own sustenance extended to all able to receive it. He re-weighted the gifts he shared from the shedding of animal blood end of the ritual spectrum toward the offering of sustaining and transforming food, stressing the shared meal and gifts of a dying man facets of cult. The mode of his doing so was strong and clear without forcing participants. As the story is told, Judas seems to have resisted and excluded himself; Peter caviled, selfinflated, but remained with the group-for a while, as did others. Receiving the gift does not appear to have helped them in the next few hours. And yet we have witnesses to the post-meal events and to the manner of the death process of Jesus who testify that something extraordinary happened. Jesus' friends are reconciled with him and with each other, with fresh questions and opportunities overriding any sense of shaming and blaming. Acts of the Apostles makes clear that at least some of those who had opposed Jesus can take up a fresh invitation to become part of the community. Can we be graciously authored by a God who loves us, and the go and do likewise?

\section{CONCLUSION}

Is there significant matter here for serious discussion of religion, even in a postmodern world? Are urgent issues of violence on the table, presented within a framework that allows them serious play? Can Bakhtin's categories offer us a way to think about the weighty challenges of interaction with our various "others"? Food for thought, food for the journey. Of course, possibilities for retaliation, competition, scapegoating, exclusion-for blood shed out of fear, for denial and reprisal, for harsh othering do not vanish. But we have been shown an alternative and offered a share in it every time we eat the bread, drink the cup.

\section{REFERÊNCIAS}

ALISON, James. Knowing Jesus. Springfield. IL: Templegate Publishers, 1993. 
ARMSTRONG, Karen. The Case for God. New York: Alfred Knopf, 2009.

ASTELL, Ann W. ; GOODHEART, Sandor (ed.). Sacrifice, Scripture, \&

Substitution: Readings in Ancient Judaism and Christianity. Notre Dame, IN: University of Notre Dame Press, 2011.

BAKHTIN, Mikhail. Art and Answerability: Early Philosophical Essays by M. M. Bakhtin. Austin: University of Texas Press, 1990.

BELL, Catherine M. Ritual: Perspectives and Dimensions. New York: Oxford University Press, 1996.

BURKERT, Walter. Homo Necans: The Anthropology of Ancient Greek Sacrificial Ritual and Myth. California: University of California Press, 1986.

CLARK, Katerina; HOLQUIST, Michael. Mikhail Bakhtin. Cambridge: Harvard University Press, 1984.

COATES, Ruth. Christianity in Bakhtin: God and the Exiled Author.

Cambridge, New York - Melbourne: Cambridge University Press, 1998.

DE VILLIERS, Pieter G.R. ; VAN HENTEN, Jan Willem (ed.). Coping with Violence in the New Testament. Leiden \& Boston: Brill, 2012.

GREEN, Barbara. Mikhail Bakhtin and Biblical Scholarship: An Introduction. Atlanta: Society of Biblical Literature Press, 2000.

How Are the Mighty Fallen? A Dialogical Study of King Saul in 1

Samuel. Sheffield: Sheffield Academic Press, 2003.

HEIM, S. Mark. Saved from Sacrifice: A Theology of the Cross. Grand Rapids, MI - Cambridge, UK: William B. Eerdmans Publishing Company, 2006.

HIRSCHKOP, Ken. Mikhail Bakhtin: An Aesthetic for Democracy. Oxford: Oxford University Press, 1999.

KILMARTIN, Edward J. The Eucharist in the West: History and Theology. ed. Robert J. Daly. Collegeville, MN: Liturgical Press, 1998.

KIRWAN, Michael. Discovering Girard. Cambridge, MA: Cowley Publications, 2005 .

MAUSS, Marcel. The Gift: The form and the Reason for Exchange in Archaic Societies. New York: W.W. Norton, 1990.

MIHAILOVIC, Alexandar. Corporeal Words: Mikhail Bakhtin's Theology of Discourse. Evanston, Illinois: Northwestern University Press, 1997.

MORSON, Gary Saul; EMERSON, Caryl. Mikhail Bakhtin: Creation of a Prosaics. Stanford: Stanford University Press, 1990. 
PALMIERI, Giovanni. "The Author" according to Bakhtin... and Bakhtin the Author. In: SHEPHERD, David (ed.). Contexts of Bakhtin, Philosophy, Authorship, Aesthetics. Amsterdam: Harwood Academic Publishers, 1998, p. 45-53.

PATTERSON, David. Bakhtin on Word and Spirit: The Religiosity of Responsibility. Cross Currents: Religion and the Intellectual Life, New York, v. 41, n. 1, p. 3344, 1991.

The Religious Aspects of Bakhtin's Aesthetics. Renascence: Essays on Values in Literature, Milwaukee, WI, v. 46, n. 1, p. 55-70, 1993.

POLZIN, Robert M. Moses and the Deuteronomist: A Literary Study of the Deuteronomic History: Part 1: Deuteronomy, Joshua, Judges. New York: Seabury, 1980.

Samuel and the Deuteronomist: A Literary Study of the Deuteronomic History: Part 2: 1 Samuel. San Francisco: Harper \& Row, 1989.

David and the Deuteronomist: A Literary Study of the Deuteronomic History: Part 3: 2 Samuel. Bloomington: Indiana University Press, 1993.

SCHILLEBEECKX, Edward. The Eucharist. New York: Sheed and Ward, 1968.

STEINFELS, Peter. A People Adrift: The Crisis of the Roman Catholic Church in America. New York: Simon and Schuster, 2003.

TAYLOR, Charles. A Secular Age. Cambridge, MA: Belknap Press of Harvard University, 2007.

USHER, Anton. Replenishing Ritual: Rediscovering the Place of Rituals in Western Christian Liturgy. Milwaukee: Marquette University Press, 2010.

WEINER, Annette. Inalienable Possessions: The Paradox of Keeping-WhileGiving. Berkeley: University of California, 1992.

WILliAMS, James G. (ed.). The René Girard Reader. New York: Crossroad, 1996. 